\title{
Assessment of pain in patients with chronic low back pain before and after application of the isostreching method
}

\author{
Avaliação da dor de pacientes com lombalgia crônica \\ antes e após a aplicação do Isostretching
}

\section{Pedro Henrique Brito da Silva, Suely Maria Satoko Moriya Inumaru*}

Universidade Estadual de Goiás (UEG), Anápolis, GO, Brazil

\begin{abstract}
Introduction: Chronic low back pain is defined as a painful disorder located between the first and the fifth lumbar vertebra and it is considered to be an important public health problem. In Brazil, approximately 10 million people are disabled as a result of this condition. Objective: To assess pain intensity and functional disability in patients with chronic low back pain before and after application of the Isostreching method. Case studies and methods: In this randomized, controlled experimental trial, 14 female individuals with chronic low back pain, aged 45-60 years, divided into control group (CG) and experimental group (EG), with 7 individuals each, twelve 45-minute sessions were held, in which 9 postures of Isostreching method were carried out in the experimental group. The control group did not undergo intervention. A sociodemographic questionnaire, the visual analogue pain scale (VAS) and the Oswestry disability questionnaire were used before and after the study period in both groups. Results: The assessment of pain and disability in the preevaluation period showed no statistically significant difference, whereas scores of pain and disability in the post-evaluation period between the two groups showed a statistically significant difference. The CG also showed no statistical difference for the VAS and Oswestry scores between the pre- and post-evaluation periods, in which it was observed an increase in the pain and disability mean scores between those periods and
\end{abstract}

* PHE: grad, e-mail: pedrobryto@gmail.com SMSMI: grad, e-mail: suelyinumaru@gmail.com 
the experimental group showed significant difference between the scores obtained in these two different periods, before and after collection. Conclusion: it is suggested that the method was effective for the group studied and proved to be suitable for the treatment of chronic low back pain.

Keywords: Spine. Low Back Pain. Disability.

\section{Resumo}

Introdução: A lombalgia crônica é definida como um distúrbio doloroso localizado entre a primeira e a quinta vértebra lombar, considerada um importante problema de saúde pública, sendo que no Brasil, aproximadamente 10 milhões de pessoas são incapacitadas em consequência desta afecção. Objetivo: avaliar intensidade de dor e incapacidade funcional de pacientes com lombalgia crônica antes e após a aplicação do Isostretching. Metodologia: estudo apresentado é do tipo experimental, controlado e randomizado, com participação de 14 indivíduos com lombalgia crônica, do gênero feminino, de 45 a 60 anos, divididas em um grupo controle (GC) e um grupo experimental (GE), com 7 indivíduos cada. Foram realizadas 12 sessões, de 45 minutos, onde foram aplicadas, no grupo experimental, 9 posturas do método Isostretching. 0 grupo controle não sofreu intervenção. Foram utilizados um questionário sociodemográfico, a escala visual analógica de dor (EVA) e o questionário de Oswestry, pré e pós o período do estudo, em ambos os grupos. Resultados: a avaliação da dor e incapacidade no momento pré entre os grupos não apresentou diferença estatística significante, enquanto que os escores de dor e incapacidade no momento pós entre os dois grupos apresentou diferença estatisticamente significante. $O$ GC também não apresentou diferença estatística para os valores de EVA e Oswestry entre os momentos pré e pós onde observamos um aumento do escore médio de dor e incapacidade entre os momentos e o grupo experimental apresentou significância entre os valores obtidos nos dois momentos de coleta pré e pós. Conclusão: sugere-se que o método foi efetivo para o grupo estudado e mostra-se adequado ao tratamento da dor lombar crônica.

Palavras-chave: Coluna. Lombalgia. Incapacidade.

\section{Introduction}

Chronic low back pain can be defined as a painful process located between the last coastal arc and the gluteal fold, whose symptoms last for more than twelve weeks. It can be triggered by various factors, such as: strains, myofascial trigger points, changes in the joints or in the intervertebral discs, and sacroiliac joint dysfunction (1). In primary care, only $15 \%$ of the specific underlying causes of the low back pains and lumbar sciatic pains are found (2 - 4). Among the pain complaints, low back pain is a common cause of morbidity and disability, being surpassed only by headaches (5).

This is a public health problem in Brazil since low back pain is the leading cause for payment of sickness benefits and the third leading cause of disability retirement. Low back pain has a multifactorial etiology including psychosocial factors, depression, sedentary urban lifestyle, obesity, smoking, bad posture while working and increased life expectancy of the population. In this sense, low back pain has a relevant economic impact on the public healthcare system, since 50 billion dollars a year are spent on expenses related to lower back pain $(2,3)$.

For proper maintenance of posture, the extensor muscles of the spine ensure the correct position of the trunk in the upright position and their performance decrease leads to instability of the spine, resulting in pain conditions and muscle fatigue. The inability to stabilize the spine due to the unbalance between trunk extensor and flexor muscles is a strong indication of the development of lumbar spine disorders. Chronic low back pain can occur as a result from a strength or isometric resistance involvement of muscles of this segment (6).

It is suggested that subjects with chronic low back pain show atrophy of lumbar paraspinal muscles and that such atrophy persists even after the symptoms regression (7). According to Macedo and Briganó (4), they avoid movements that can cause pain, which 
especially leads to atrophy of the multifidus muscles, then causing greater pain intensity and disuse of the lumbar segments of the spine. With strength and isometric resistance exercises aimed at these muscles, the atrophy is reversible and the low back pain recurrence is reduced (9).

Studies demonstrate that individuals with chronic low back pain experience fast fatigue due to strength and resistance deficit of the flexor and extensor muscles of the lumbar spine, which provide stability for this segment $(7,8)$. According to Barbosa and Gonçalves (8), the relation between strength and isometric resistance of the lumbar spinae erector muscles with the maintenance of the vertebral column functional and physical integrity is that, with muscle fatigue, defined as a reduction on the neuromuscular system to generate strength or to perform work, might occur on the passive elements (capsules, ligaments and intervertebral disks) responsible for the vertebral column stability during the execution of specific movement patterns of some sports, resulting in damages to structures sensible to distension, producing pain.

The role of physical activity as a therapeutic resource for the prevention and treatment of low back pain has received great attention in recent years (10). Isostreching can be included among the methods of global approach. It is a global postural re-education method, created in France 30 years ago by the physiotherapist Bernard Redondo, and promotes respiratory control, control of emotions and body control in space plus intense muscular work. This is why it is classified as a postural method, since the exercises are performed with the objective of correcting abnormal curvatures of the spine in association with deep and prolonged exhalation and isometric muscle contraction, especially the deep paraspinal, abdominal, hip flexor and pelvic floor muscles. It is also classified as "global" because many muscle groups throughout the body are used in each posture. It also demands self-growth from the spine. Thus, it stimulates proprioception, coordination and body awareness (11).

According to Mann et al., (12) the Isostreching exercises are commonly and widely used in clinical practice by physical therapists and professionals with satisfactory results. However, Pizol and Oliveira (13), Macedo and Briganó (4) demonstrate that this method is effective in the treatment of low back pain, but it was not found superior to other techniques, such as the segmental stabilization and manual therapy. Furthermore, there is little evidence in the scientific literature on its effectiveness in patients with chronic low back pain. Therefore, this study aims to evaluate the intensity of pain and functional disability before and after the application of Isostreching techniques in patients with chronic low back pain at the Clinic School of the Superior School of Physical Education and Physiotherapy of the State of Goiás (ESEFFEGO).

\section{Study cases and methods}

This is a randomized controlled trial. The sample consisted of 14 individuals with a clinical diagnosis of chronic low back pain who were on the waiting list for physical therapy treatment at the Clinic School of Physiotherapy at ESEFFEGO. Participants were to the research team in accordance with the inclusion and exclusion criteria, as detailed in Figure 1, after an individualized clinical evaluation by a physical therapist, a blinded evaluator, who were in charge of screening patients in the clinic.

It was used a socio-demographic questionnaire, which was structured by the researchers, containing items related to personal data and some clinical information about the subjects of the study (age, gender, occupation, etc.). The visual analog scale (VAS) was also used to assess the individuals' pain intensity. The Oswestry disability questionnaire was applied to identify the impact of pain on daily and professional activities of the participants. The assessments, implementation and analysis of the questionnaires and VAS before and after intervention were performed by a blinded evaluator.

The 14 individuals were randomly divided into two groups by picking the participants' names at random from an opaque envelope, one by one. The first seven names were assigned to the control group and the remaining seven to the experimental group. The sample size was calculated using 50 per cent statistical power, 30 per cent of improvement in the experimental group (VAS and Oswestry Questionnaire) and standard deviation of two points, reaching the number of seven participants in each group. A five per cent level of significance was used. All participants filled out the questionnaires, but only the experimental group performed Isostreching exercises. Both the seven individuals in the experimental group and the seven individuals in the control group completed the treatment, so there was no loss of subjects during the study. 


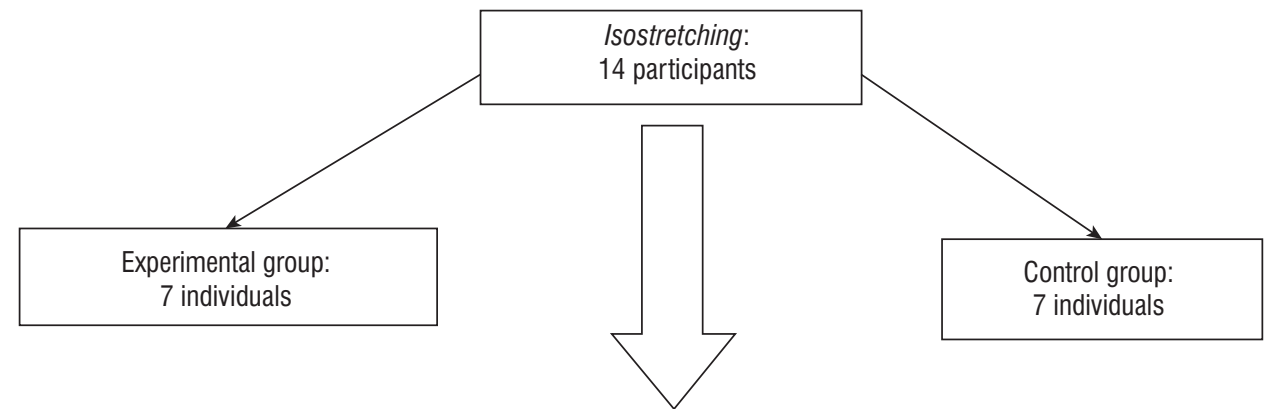

Inclusion criteria: female; aged $45-60$ years; be literate; be able to use verbal communication; be clinically diagnosed as having chronic low back pain and be in the waiting list for the physical therapy tratment at the clinic school at ESEFFEGO. must declare to agree by signing the informed consent form.

Exclusion criteria: male; if treatment is abandoned during research or if is absent for three consecutive or not consecutive sessions; if indormed consent form is not signed; if suffers from any severe and clinically diagnosed neurological, respiratory or orthopedic pathology (fractures, instabilities, hemiated disc, spinal stenosis or tumors), cognitive deficit or if undergoing physical therapy treatment.

Figure 1 - Diagram representing the division of the groups and the inclusion and exclusion criteria

Twelve 45-minute in group sessions were held in April, 2013, three times a week. The questionnaires' application and reapplication and VAS were respectively performed before the first and after the last session by a blinded evaluator. The site chosen for data collection was a large, airy room located on the premises of ESEFFEGO clinic school.

Before starting the first application of the Isostreching method, a warm-up session to teach the basic requirements for correct posture was held: the adequate alignment of the vertebral column, understood as rectification of vertebral curvatures; body awareness exercises through pelvic anteversion and retroversion movements in the upright position; diaphragmatic and prolonged breathing and self-stretching.

The selection of postures was adapted from those described in the literature $(12,13,14,15)$ and followed these guidelines:

1) in each session, nine postures were chose; all of them were symmetrical to make their implementation easier, and were carried out in dorsal decubitus (four postures), seated (two postures) and orthostatic position (three postures);

2) the selected postures prioritized a focus on the respiratory chains, hip anterointernal positions and the main posterior chain, since these chains have been reported to be more affected by weakness and muscle shortening in patients with chronic low back pain (6);

3) a progression of posture was performed, i.e., exercises had no changes in position. Also, balls and sticks were not used, so that the intervention protocol could be used in any situation;

4) the time for which each exercise was maintained was determined by the time taken to exhale through pursed lips, which should last around ten seconds;

5) each posture was previously demonstrated by the researcher/instructor before the volunteers performed it;

6) the researcher/instructor corrected any volunteers who might not have been performing the exercise correctly, through verbal and/or tactile stimulation.

After the research, the control group also performed the exercises based on the Isostreching method, following the same postures and number of sessions attended by the experimental group. Subsequently, all the 14 individuals were referred for conventional physical therapy treatment at ESEFFEGO clinic school. 
This study was conducted in accordance with the Guidelines and Regulating Norms for Research involving Human Beings (Resolution 466/2012 of the National Health Council). It was duly submitted, evaluated and approved by the Research Ethics Committee at Goiânia Emergency Hospital (HUGO), legal opinion number 255,594, being started only after approval.

The research participants were properly informed by the researchers about the study's objective and its relevance to society. The information was communicated orally, in writing and in details through the Informed Consent (IC). The individuals who agreed with the research signed the informed consent form.

Descriptive analyses were carried out by using frequency measures and percentage, (mean) central tendency and variability (standard deviation) of the VAS score and questionnaires. The inferential statistical analysis was performed using BioEstat 5.0 software and also the analysis of variance (ANOVA) in case of significance, followed by Tukey test and by paired student's t test between the (pre- and post-intervention tests) moments of independent and intragroup data collection (experimental or control group) between the moments and between the groups, considering a level of significance of $95 \%(p=0.05)$.

\section{Results}

It was initially proposed a sample of 30 patients of both sexes, according to the waiting list of the institution. However, due to non-adherence of all patients to the research, 14 women aged 45 to 60 with low back pain complaints were evaluated and divided into two groups of seven subjects each - a control group (CG) and an experimental group (EG).

CG had a mean age of $50.43( \pm 4.75)$ years, with a BMI of $27.85( \pm 4.6) \mathrm{kg} / \mathrm{cm}^{2}$, and 6 subjects (85.7\%) of the sample were of Caucasian ethnicity; one individual was of African descent and all the group's volunteers were married. Regarding the level of education in the CG, 42.8\% ( $\mathrm{n}=3)$ had finished high school, one individual had not finished high school; one individual had finished primary school and $28.5 \%$ $(n=2)$ had incomplete primary education.

The average age of experimental group was 50.57 $( \pm 4.8)$ years, the mean BMI was $27.68( \pm 5.54) \mathrm{kg} /$ $\mathrm{cm}^{2}$, six individuals were Caucasian and 1 was dark skinned. In the group, five volunteers (71.4\%) were married, one was divorced and one was a widow. Regarding the level of education, four individuals (57.12\%) had incomplete primary education and three subjects had finished high school.

BMI and age values between CG and EG showed no statistically significant difference. Mean value, standard deviation and p-value for Student's t-test and ANOVA of one variable are shown on Table 1.

Table 1 - Mean value, standard deviation and p-values for age and BMI between CG and EG

\begin{tabular}{lcc}
\hline \multicolumn{1}{c}{ Group } & Age (in years) & BMI $\left(\mathrm{Kg} / \mathrm{cm}^{2}\right)$ \\
\hline $\mathrm{CG}$ & $50.43( \pm 4.75)$ & $27.85( \pm 4.6)$ \\
$\mathrm{EG}$ & $50.57( \pm 4.8)$ & $27.68( \pm 5.54)$ \\
P-value & 0.9563 & 0.4582 \\
\hline
\end{tabular}

Note: Captions: $\mathrm{CG}=$ control group; $\mathrm{EG}=$ experimental group; $\mathrm{BMI}=$ Body Mass Index.

As regards the working activities of the CG volunteers, four of them were homemakers, one was a hairdresser, one was retired and one was an attendant. Five volunteers of the experimental group were homemakers, one was a school cook and one of them was retired.

Among the women in CG, over 70\% (n $=5)$ had been having low back pain for more than 24 months and two of them had been having low back pain for 12-24 months, whereas $85.7 \%$ of EG volunteers $(n=$ 6 ) had been having chronic low back pain for more than 24 months and one of them for 12 to 24 months.

As regards physical activity, it was observed an attendance of twice a week: three women (42.84\%) of the CG and four volunteers (57.12\%) of the EG. The others reported having no regular physical activity.

EG underwent a physical therapy intervention protocol for 3 weekly sessions, totaling 12 sessions of treatment and both groups were evaluated in two pre and post-intervention moments using VAS and Oswestry Index Questionnaire.

Pain assessment by VAS in the pre-intervention moment between groups showed no statistically significant difference with $p$-value of 0.8159 , whereas pain scores in the post moment between the two groups showed a statistically significant difference of 0.003 (p-value). 
GC also showed no statistical difference for VAS values between pre and post-intervention moments $(\mathrm{p}=$ 0.3208 ), when it is observed an increase in average pain score between moments. There was significance between the values found in EG in both (pre and post-intervention) moments of collection ( $p=0.0006)$ (Table 2).

As regards the Oswestry Questionnaire, the preintervention moment between groups showed no statistically significant difference $(p=0.6372)$, but the data of the groups in the post-intervention moment were significantly different $(p=0.0151)$.

CG showed no statistical difference between pre and post-intervention moments ( $p=0.8479$ ), whereas EG showed highly significant statistical difference between pre and post-intervention moments with $p$-value of 0.0010 (Table 3).

Table 2 - Mean value, standard deviation of the VAS scores for CG and EG in pre and post-intervention moments and pvalues among moments (inter-group and intra-group)

\begin{tabular}{lccc}
\hline \multicolumn{1}{c}{ Groups } & Pre-VAS score & Post-VAS score & $p$-value \\
\hline CG & $5.85( \pm 2.41)$ & $6.43( \pm 2.37)$ & 0.3208 \\
EG & $5.57( \pm 2.22)$ & $1.43( \pm 1.13)$ & $0.0006^{*}$ \\
$p$-value & 0.8159 & $0.003^{*}$ & \\
\hline
\end{tabular}

Note: Captions: ${ }^{*}=$ Significant mean difference; $C G=$ control group; $E G=$ experimental group; $V A S=$ Visual Analog Scale.

Table 3 - Mean value and standard deviation of Oswestry scores for CG and EG in pre and post-intervention moments and $p$-values among moments (inter-group and intra-group)

\begin{tabular}{lccc}
\hline \multicolumn{1}{c}{ Groups } & Pre-Oswestry score & Post-Oswestry score & $p$-value \\
\hline CG & $35.42( \pm 8.7)$ & $36.28( \pm 8.36)$ & 0.8479 \\
EG & $37.71( \pm 8.97)$ & $23.42( \pm 8.61)$ & $0.0010^{*}$ \\
$p$-value & 0.6372 & $0.0151^{*}$ & \\
\hline
\end{tabular}

Note: Captions: ${ }^{*}=$ Significant mean difference; $\mathrm{CG}=$ control group; $\mathrm{EG}=$ experimental group.

\section{Discussion}

The influence of gender on functional disability in patients with chronic low back pain has been explored in several studies, but the results are divergent. Many authors point to an association between female gender, disability and chronic low back pain, since women possess anatomical and biomechanical characteristics, such as lower height, lower bone mass, reduced muscle mass, in addition to performing housework and having a job, lead to spinal overload $(16,17,18,19)$. However, other studies show that men are more likely to have lumbar spine injuries that generate absenteeism. They are also more likely to develop disabilities than women $(20,21)$. In this study, it was not possible to make the comparison between genders, as male subjects did not show interest on the research. These patients were called by phone, but they did not show up for the screening tests and selection. This way, our sample only consisted of women.

Regarding age, there were individuals aged 45-60 years, with an average of $50.43( \pm 4.75)$ years in the control group and $50.57( \pm 4.8)$ in the experimental group, corroborating the results found in a study conducted by Ferreira et al. (22), with chronic low back pain patients with an average age of $51.77( \pm 3.22)$ years. The relation between aging, pain intensity and higher frequency of disability has been described by some authors $(17,19,23,24)$, which corroborates physiology, and it is explained by the fact that aging may result in progressive degenerative changes of the spinal column. It may then result in the wear of the musculoskeletal system of the spine, causing painful 
episodes, since those tissues have nociceptors that are able to generate painful stimuli, which suggests that older individuals have greater vulnerability to problems related to the lumbar spine $(25,26)$.

Concerning ethnic groups, a broad participation share of Caucasians was observed, representing $85.7 \%$ in both CG and EG. Almeida et al. (27) came to different results as most of the individuals with chronic low back pain were of African descent. Their study was conducted in the city of Salvador, where there is a predominance of Black people. However, Ferreira et al. (22) found similar results to this research, since the study was conducted in Pelotas, in the south of Brazil, where Caucasians are an absolute majority. The White population is $45.9 \%$ (28) in Goiás, which can be a reason for the further incidence of chronic low back pain in the participants of this study, since most of the state's population is of Caucasian origin.

The results obtained for the BMI show that the samples assessed in both control and experimental group are predominantly overweight. Individuals with higher BMI will be expected to have higher physical strain and more difficulty to perform their activities of daily living, which may be related to disability. Moreover, when extra charge is placed on bones, muscles and joints, biomechanical changes of the spine may occur, which consequently increases the risk of low back pain in overweight and obese people (29). Some studies have found an association between BMI, chronic low back pain intensity and disability $(17,30,31)$, while others do not support such an association (32).

Activities performed at work can contribute to the risk of disability related to low back pain. It can be noted that workers who are subject to greater physical demands, such as those who carry heavy objects and experience vicious and fast paced repetitive working positions, may have higher prevalence of chronic pain and disability (33). The working environment includes issues that often go beyond physical requirements, such as service execution time, high productivity and product/work quality (30). There is evidence, however, that factors related to labor activities did not influence the pain symptoms and disability in a rural population with chronic low back pain that had been followed for 12 years (32).

However, in this study, it was not possible to analyze in further details how occupations are related to chronic low back pain and disability, as a few individuals from the sample had a job. With regard to subjects who had paid work, their work schedules and postures adopted in the work place that can influence pain intensity and consequent disability could not be defined. Almeida et al. (27) also showed the same limitation on their population-based study in Salvador.

Regarding marital status and low back pain, a higher prevalence of married individuals was observed. The studies of Almeida et al. (27) and Silva, Fassa and Vale (30) agree with this finding. Marital status may be related to greater ergonomic exposure, both at home and at work. Nevertheless, as low back pain is influenced by psychosocial factors, the other group, represented by single, divorced and widowed women, could be influenced by factors like low social and family support, which would have a negative impact on their health conditions (34).

As for the duration of pain, it was observed that most participants in the experimental group (87.5\%) and control group (70\%) had been having chronic low back pain for more than 24 months. A similar length of time was found in a study about low back pain, in which was observed that $37.7 \%$ of subjects had been having low back pain for more than 36 months (19). It should be emphasized the importance of the duration of low back pain: it affects many aspects of life and can lead to sleep disorders, irritability and depression, which contributes to chronicity of pain episodes and subsequent disability (35). Wobby, Urmston and Watson (18), in accordance with Henschke et al., (23) reported that persistent low back pain for more than six weeks can disable $45 \%$ of the subjects with such clinical condition.

Another variable that may be associated with disability and low back pain is the practice of physical activity. Individuals who regularly do physical activities are more likely to have several risk factors for diseases reduced, and hence, lipid metabolism is improved, body weight control is controlled and selfperception of health condition is enhanced, among other benefits (36). Bento, Paiva and Siqueira (37) found that $43.3 \%$ of individuals with chronic low back pain performed some type of physical activity, which confirms the results presented in this study. Hence, individuals who are affected by pain conditions in the lumbar spine commonly report intolerance to physical activity because of pain exacerbation and, in these cases, the fear of pain is more disturbing than the movement performed, which predisposes to functional disability and sedentary lifestyle (38).

The participants level of education was considered to be low. Similar data were found in national 
studies $(27,30)$ and they differ from studies conducted in developed countries $(16,39)$. It is understood that one's education level determines his/her eligibility to various job opportunities. Thus, individuals with less schooling generally perform activities that require more physical effort, in contrast to people who have higher education, better socioeconomic conditions, broader access to the health system and better information about health care (29).

The experimental group showed a significant reduction of pain episodes and functional impairment when compared to the results before and after the intervention, unlike the control group, whose individuals experienced worsening of the pain and of the functional impairment in the same period. It should also be noted a considerable outcome when we compared the control group to the experimental group. Mann et al. (12) conducted a case study to investigate the influence of the Isostreching method for treating chronic low back pain. Twenty female college students were randomly assigned into two groups: ten students with low back pain in the experimental group underwent a ten-session intervention based on Isostreching (ten postures); and ten students in the control group, who had no low back pain, did not undergo any intervention. The results showed a decrease in low back pain, assessed by VAS, as well as improved functional impairment in all individuals, which was assessed by the Roland Morris questionnaire, as well as significant improvements on muscle strength, muscle stretching and balance. The method proved to be effective for treatment of low back pain in the study group, which corroborates the present study.

Facci (40) conducted a case study to assess the benefits achieved in patients with chronic low back pain, who had been submitted to the Isostreching method. The outcomes were significant and similar to those of this study, in which twenty patients eleven women and nine men - held twelve sessions of the method three times a week. At the beginning and end of treatment, various assessment tools were used, such as: the Medical Outcome Study 36 - Item Short - Form Health Survey (SF-36) to check if there had been any enhancement of quality of life; the VAS to identify intensity of pain; and the Roland Morris questionnaire to score functional disability. It was also assessed the influence of the method on muscle strength of abdominal and spinal extensor muscles and flexibility. Statistically significant benefits were found with regard to all prevailing aspects in most patients. This study could verify the efficacy of the Isostreching method in pain enhancement and disability in patients with chronic low back pain.

Thus, these studies explain the enhancement in pain and functional disability based on the assumption that the Isostreching method provides flexibility and muscle strengthening, consequently improving postural control through exercise of antagonist muscles and isometric stretching of the agonist muscles, as mobility restriction and lumbar spine range of movement in patients with chronic low back pain are observed, when compared to healthy subjects (11). Therefore, the increased flexibility reduces the possibility of muscle weakness and muscle retraction, which optimizes the length-tension relationship. It consequently increases the individuals' performance and participation in recreational, working and functional activities, which reduces painful conditions (12).

Furthermore, muscle weakness in the abdominal region and reduction of the activities of the deep paraspinal muscles are present in patients with chronic low back pain. Muscles with adequate strength are less likely to reach ischemic levels and fatigue when compared to weak muscles, which allows a better biomechanical alignment and prevents excessive muscle tension and postural compensation. It helps reducing the risk of injury and low back pain, as well as the effort required to carry out activities of daily living (41).

Some studies have made a comparison between the Isostreching method and conventional physical therapy techniques concerning the elimination of low back pain, as found in the study of Durante and Vasconcelos (42). They conducted a case study in order to compare the Isostreching method and conventional kinesiotherapy in the treatment of pain and disability caused by lumbago. Pain scores and its impact on functional capacity were assessed with the VAS and Oswestry scores. Six women were randomly divided into two groups and ten individual sessions were held: group A carried out nine postures of the Isostreching method, and group B carried out stretching of the lower-limb muscles and strengthening of the transverse abdominal muscle. The results showed that there was a difference in pain only in group A. However, both groups showed improvement with regards to disability, with no difference between them. In conclusion, the Isostreching method was not found 
superior to conventional kinesiotherapy in the treatment of low back pain, but it was effective in reducing pain and disability.

The results showed a statistically significant difference for all the analyzed parameters. Manual therapy and kinesiotherapy had significant effects on pain relief, quality of life and disability of patients with low back pain. However, manual therapy demonstrated to cause significant improvement when compared to exercise therapy in patients with chronic low back pain. Those authors also point out that rehabilitation based on physical exercises enhances physical function and has modest effects on pain, but has a positive effect in patients with chronic low back pain.

Lopes et al. (43) further found that the effects of the method were first noted by the patients on the eighth session and could be fully observed until the end of treatment. Of the 20 patients reassessed, however, only two had worsened pain symptoms in the three parameters (VAS, SF-36 and Roland Morris questionnaire), which represented only $10 \%$ of the patients. In addition, the author points out that monitoring patients after treatment could be relevant for a certain period of time in order to confirm whether the benefits achieved would be kept or not.

\section{Conclusion}

This study shows that the Isostreching method can be an effective and inexpensive tool for physical therapists when treating patients with chronic low back pain and in order to reduce disability and pain. The Isostreching method has become a more popular treatment option for patients with low back pain, but studies are few and they do not use the same methodology. Further research is necessary, as well as larger sample size.

In spite of having a small sample size as a major limitation, it was possible to assess pain intensity of 14 study participants as well as the impact of pain episodes on ADLs through the Oswestry questionnaire, which suggests that the Isostreching method promoted a significant reduction in pain intensity and functional disability in the EG subjects when compared to those of the CG who did not undergo physical therapy activities in the same period and had higher scores on the pain intensity and functional disability scales.

\section{References}

1. Tsukimoto GR, Riberto M, Brito CA, Battistella LR. Avaliação Longitudinal da Escola de Postura para dor lombar crônica através da aplicação dos questionários Roland-Morris e Short Form Health Survey (SF-36). Acta Fisiatr. 2006;13(2):63-9.

2. Ferreira MS, Navega MT. Efeitos de um programa de orientação para adultos com lombalgia. Acta ortop bras. 2010;18(3):127-31.

3. Hoy D, Brooks P, Blyth F, Buchbinder R. The epidemiology of a low back pain. Best Pract Res Clin Rheumatol. 2010;24(1):769-81.

4. Macedo CSG, Briganó JU. Terapia manual e cinesioterapia na dor, incapacidade e qualidade de vida de indivíduos com lombalgia. Espaç saúde. 2009;10(2):1-6.

5. Machado GF, Bigolin SE. Estudo comparativo de casos entre a mobilização neural e um programa de alongamento muscular em lombálgicos crônicos. Fisioter Mov. 2010;23(4):545-54.

6. Macedo CSG, Debiagi PC, Andrade FM. Efeito do Isostreching na resistência muscular de abdominais, glúteo máximo e extensores de tronco, incapacidade e dor em pacientes com lombalgia. Fisioter Mov. 2010;23(1):113-20.

7. Gonçalves M, Barbosa FSS. Análise de parâmetros de força e resistência dos músculos eretores da espinha lombar durante a realização de exercício isométrico em diferentes níveis de esforço. Rev Bras Med Esporte. 2005;11(2):109-14.

8. Barbosa FSS, Gonçalves M. Comparação entre protocolos de exaustão e de 30 segundos utilizados na avaliação da fadiga eletromiográfica dos músculos eretores da espinha. Rev Bras Fisioter. 2005;9(1):77-83.

9. Beloube DP, Costa SEM, Junior EAB, Oliveira RJDP. 0 método Isostreching nas disfunções posturais. Rev Fisioter Bras. 2003;4(1):72-4.

10. Ribeiro CAN, Moreira D. O exercício terapêutico no tratamento da lombalgia crônica: uma revisão da literatura. Rev Bras Ciênc Mov. 2010;18(4):100-8.

11. Redondo B. Isostreching: A reeducação da coluna. Piracicaba: Gráfica Riopedrense Editora; 2006. 
12. Mann L, Kleinpaul JF, Weber P, Mota CB, Carpes FP. Efeito do treinamento de Isostreching sobre a dor lombar crônica: um estudo de casos. Motriz. 2009; 15(1):50-60.

13. Pizol GZ, Oliveira MR. Exercício de Isostreching e estabilização segmentar na lombalgia crônica: um estudo comparativo [monography]. Vitória: Faculdade Católica Salesiana do Espírito Santo; 2011.

14. Duarte MFR. Efeito de um programa/terapia com base no Isostreching e mobilização lombar com bola suíça em trabalhadores portadores de dor lombar [dissertação]. Porto: Universidade do Porto; 2010.

15. Kano LP, Silvério MG, Siqueira CPCM. 0 efeito do método Isostreching na dor musculoesquelética e na qualidade de vida dos funcionários da CEI-HU. Ter Man. 2010;8:147-51.

16. Soucy I, Truchon M, Côté D. Work-related factors contributing to chronic disability in low back pain. Work. 2006;26(1):313-26.

17. Webb R, Brammah T, Lunt M, Urwin M, Allison T, Symmons D. Prevalence and predictors of intense, chronic, and disabling neck and back pain in the UK general population. Spine. 2003;28(11):1195-202.

18. Wobby SR, Urmston M, Watson PJ. Self-efficacy mediates the relation between pain-related fear and outcome in chronic low back pain patients. Eur J Pain. 2007;11(1):711-8.

19. Wynne-Jones G, Dunn KM, Main CJ. The impact of low back pain on work: a study in primary care consulters. Eur J Pain. 2008;12(2):180-8.

20. Smeets RJEM, Wittink H, Hidding A, Knottnerus JA. Do patients with chronic low back pain have a lower level of aerobic fitness than healthy controls? Spine. 2006;31(1):90-7.

21. Wijnhoven HAH, De Vet HCW, Picavet HSJ. Sex differences in consequences of musculoskeletal pain. Spine. 2007;32(12):1360-7.

22. Ferreira GD, Silva MC, Rombaldi AJ, Wrege ED, Siqueira FV, Hallal PC. Prevalência de dor nas costas e fatores associados em adultos do sul do Brasil: um estudo de base populacional. Rev Bras Fisioter. 2011;15(1):31-6.
23. Henschke N, Maher CG, Retshauge KM, Herbert RD, Cumming RG, Bleasel J. Prognosis in patients with recent onset low back pain in Australian primary care: inception cohort study. BMC Musculoskelet Disord. 2008;337(171):154-7.

24. Sardá JJ, Kupek E, Cruz RM. Preditores biopsicossociais da incapacidade física e depressão em trabalhadores do setor frigorífico atendidos em um programa de reabilitação profissional. Acta Fisiat. 2009;16(2):76-80.

25. Gourmelen J, Chastang JF, Ozguler A, Lanoe JL, Ravaud JF, Leclerc A. Frequénce des lombalgies dans la population française de 30 à 64 ans: résultats issus de deux enquêtes nationales. Ann Readapt Med Phys. 2007; 50(1):640-4.

26. Rathmell JP. A 50 years old man with chronic low back pain. J Am Med Assoc. 2008;299(17):2066-77.

27. Almeida ICGB, Sá KN, Silva M, Baptista A, Matos MA, Lessa I. Prevalência de dor lombar crônica na população da cidade de Salvador. Rev Bras Ortop. 2008; 43(3):96-102.

28. Brasil. Instituto Brasileiro de Geografia e Estatística. Síntese de indicadores sociais e uma análise das condições de vida da população brasileira. Rio de Janeiro; 2010.

29. Salvetti MG, Pimenta CAM, Braga PE, Côrrea CF. Incapacidade relacionada à dor lombar crônica: prevalência e fatores associados. Rev Esc Enferm USP. 2012;46(1):16-23.

30. Silva MC, Fassa ACG, Valle NCJ. Dor lombar crônica em uma população adulta do sul do Brasil: prevalência e fatores associados. Cad Saúde Pública. 2004; 20(2):377-85.

31. Urquhart DM, Bell R, Cicuttini FM, Cui J, Forbes A, Davis SR. Negative beliefs about low back pain are associated with high pain intensity and high level disability in community-based women. BMC Musculoskeletal Disord. 2008;9(1):148-59.

32. Holmberg SAC, Thelin AG. Primary care consultation, hospital admission, sick leave and disability pension owing to neck and low back pain: a 12 years prospective cohort study in a rural population. BMC Musculoskeletal Disord. 2006;7(66):1-8. 
33. Andrusaitis SF, Oliveira RP, Barros Filho TEP. Study of prevalence and risk factors for low back pain in truck drives in the state of São Paulo, Brazil. Clinics. 2006;61(6):503-10.

34. Lee P, Helewa A, Goldsmith CH, Smythe HA, Stitt LW. Low back pain: prevalence and risk factors in an industrial setting. Rheumatology. 2001;28(2):346-51.

35. Heneweer H, Aufdemkampe G, Van Tulder MW, Kiers H, Stappaets KH, Vanhees L. Psychosocial variables in patients with sub(acute) low back pain: an inception cohort in primary care physical therapy in the Netherlands. Spine. 2007;32(5):586-92.

36. Hespanhol Júnior HC, Oliveira KTF, Oliveira TGV, Girotto N, Carvalho ACA, Lopes AD. Efeito do método Isostreching na flexibilidade e nível de atividade física em indivíduos sedentários saudáveis. Rev Bras Ciênc Mov, Brasília. 2011;19(1):26-31.

37. Bento AAC, Paiva ACS, Siqueira FB. Correlação entre incapacidade, dor - Roland Morris, e capacidade funcional - SF-36 em indivíduos com dor lombar crônica não específica. e-Scientia.2009;2(1).

38. Mascarenhas CHM, Santos LS. Avaliação da dor e incapacidade funcional em indivíduos com lombalgia crônica. J Health Sci Inst. 2011;29(3):205-8.
39. Mccraken LM. Social context and acceptance of chronic pain: the role of solicitous and punishing responses. Pain. 2005;113(1):155-9.

40. Facci LMO. Isostreching no tratamento da lombalgia crônica. Fisioter Bras. 2006;7(2):245-61.

41. Monte-Raso VV, Ferreira PA, Carvalho MS, Rodrigues JG, Martins CC, Iunes DH. Efeito da técnica Isostreching no equilíbrio postural. Fisioter Pesqui. 2009;16(2).

42. Durante H, Vasconcelos ECLM. Comparação do método Isostreching e cinesioterapia convencional no tratamento da lombalgia. Semina cienc biol saúde. 2009;30(1):83-90.

43. Lopes PM, Mackert TC, Yau MCMH, Facci LM. Isostreching no tratamento da lombalgia crônica. Fisioter Bras. 2006;7(2):99-103.

Received: 10/03/2013

Recebido: 03/10/2013

Approved: 05/28/2015

Aprovado: 28/05/2015 
